\title{
The IGLVA gene as a STS in the human immunoglobulin lambda light chain variable gene locus (located at 22q11)
}

\author{
P.Chuchana, D.Alexandre, G.Lefranc and M.-P.Lefranc* \\ Laboratoire d'Immunogénétique Moléculaire, LIGM, URA CNRS 1191, Université Montpellier II, CC \\ 012, Place E.Bataillon, 34095 Montpellier Cedex 5, France
}

The human immunoglobulin lambda light chain gene locus (IGL) is located on chromosome $22(1-3)$ at band $q 11$. The $V \lambda$ genes belong to seven subgroups (4). All the $\lambda$ proteins sequenced so far fall into the subgroups I, II, III and VI. The subgroups IV, V and VII were defined from nucleotide sequences (4). A pseudogene, IGLVA, belonging to none of these subgroups and

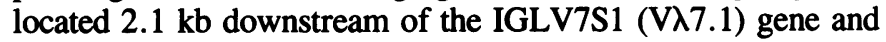
$7.2 \mathrm{~kb}$ upstream of the IGLV1S1 (V $\lambda 1.1)$ gene, has previously been described (5) (EMBL accession number X14613). We have defined this information gene as a sequence-tagged site (STS), designated IGLVA[/22q11], for inclusion in the human genome map. Using the polymerase chain reaction (PCR) described below, a fragment of the expected size (469 bp) was amplified from the positions 125 to 593 of the human IGLVA gene (5). The amplified fragment was purified, uniformly radiolabelled, and used to probe seventeen human genomic DNAs by Southern. As anticipated, a single $7.0 \mathrm{~kb}$ EcoRI fragment was detected demonstrating the unique character of the amplified sequences. HindIII identifed two fragments $(1.6 \mathrm{~kb}$ and $2.3 \mathrm{~kb})$, due to the presence of an internal HindIII site in the PCR product, as expected from the IGLVA sequence (5). BamHI identified two allelic restriction fragments of $4.7 \mathrm{~kb}$ (IGLVA*A1) and $3.0 \mathrm{~kb}$ (IGLVA*A2).

\section{PCR Primers:}

Forward (125-143 in ref. 5) TAATCCGTGTGCTCAGGAA Reverse (593-576 in ref. 5) GGAGTGATCAGCCTTGTC

PCR Components: $2 \mu \mathrm{g}$ of human genomic DNA, 40 pmoles of each oligonucleotide, $200 \mu \mathrm{M}$ dNTPs, and 2.5 U Taq polymerase (Perkin Elmer Cetus) in $100 \mu \mathrm{l}$ of $1 \times$ PCR buffer $(20 \mathrm{mM} \mathrm{KCl}$, $20 \mathrm{mM}$ Tris- $\mathrm{HCl}, \mathrm{pH} 8.3$ (at room temperature), $1.5 \mathrm{mM}$ $\mathrm{MgCl}_{2}, 0.1 \%$ (w/v) gelatin).

PCR Profile: $95^{\circ} \mathrm{C}$ for 3 minutes; $55^{\circ} \mathrm{C}$ for 10 minutes. 30 cycles each at: $72^{\circ} \mathrm{C}$ for 30 seconds; $95^{\circ} \mathrm{C}$ for 30 seconds; $55^{\circ} \mathrm{C}$ for 30 seconds.
Anticipated sequence of the PCR product: (primers are underlined, and the internal HindIII site is indicated).

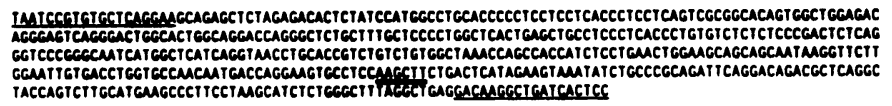

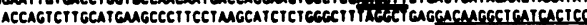

\section{REFERENCES}

1. Erickson,J. et al. (1981) Nature 294, 173-175.

2. de la Chapelle,A. et al. (1981) Hum. Genet. 57, 253-256.

3. McBride,O.W. et al. (1982) J. Exp. Med. 155, 1480-1490.

4. Chuchana,P. et al. (1990) Eur. J. Immunol. 20, 1317-1325.

5. Alexandre,D. et al. (1989) Nucl. Acids. Res. 10, 3975. 